\title{
NEWSPAPER REPORTERS' ROLE EFFECTIVENESS: A COMPARATIVE STUDY OF TWO LEVELS OF HIERARCHY
}

\author{
SANJAY KUMAR SINGH \\ New Delhi Institute of Management, \\ Tughlakabad Institutional Area, New Delhi, INDIA \\ sanjaysinghdu@yahoo.com \\ PARAMJEET KAUR DHILLON \\ Dept. of Psychology \\ University of Delhi \\ Delhi, INDIA
}

\begin{abstract}
Hardly any behavioural scientist ever thought of empirically studying newspaper reporters from a psychological perspective. Realising the dearth of study from psychological viewpoints this investigation was designed to examine the relationships as well as relative impact of the antecedent variables of Background information, organisational climate, organisational role stress, and journalistic writing attitude on to the role effectiveness of the lower level reporters and the higher level reporters. The results obtained were discussed in the light of the past researches in the area of effectiveness in-a-rolein-an-organisation.
\end{abstract}

\section{OPSOMMING}

Bykans geen gedragswetenskaplike het al aan die idee gedink om koerant-verslaggewers vanuit 'n sielkundige perspektief te bestudeer nie. Gegewe die skaarste aan navorsing vanuit 'n sielkundige gesigshoek, is hierdie ondersoek ontwerp om die verhouding sowel as die relatiewe impak van oorsaaklike veranderlikes van agtergrondinligting, organisasieklimaat, organisatoriese rolstres en die joernalistieke skryfhouding op die roldoeltreffendheid van die laevlak verslaggewers en die hoëvlak verslaggewers te ondersoek. Die verkreë resultate word bespreek in die lig van die vorige navorsing ten opsigte van roldoeltreffenheid in 'n organisasie.

The psychological investigation in the area of newspaper journalism has its own importance as it plays the role of a bridge between the people and the government. It lets the government know the needs as well as the aspirations of its people and also inform the latter about the intentions as well as limitations of the former. Moreover, the newspaper of any nation is identical to a mirror which reflects the state of affairs of its society and also the government of the days.

This very pious role performed by the fourth estate is solely dependent on its staff reporters/correspondents. They are the one who constantly and meticulously get themselves involved in collecting as well as writing relatively complete and authentic socially relevant information in their respective newspapers. As compared with other professions around, the profession of newspaper journalism is endowed with lots of professional risks/hassles, but this does not deter them to give their best. The kind as well as the nature of risks/hassles are such that they might affect them adversely to their psycho-physical-social health. But despite all these odds, the staff reporters/correspondents of a newspaper function like a champion and help their newspaper to earn good image into the mindset of the society at large. Without them the newspaper would be a dead entity as the staff reporters/correspondents are its heart beat as well as life blood.

Therefore studying the role effectiveness of staff reporters/ correspondents of newspaper organisation from psychological viewpoints holds much importance as they are involved in somewhat different but interesting and exciting roles and functions than the members of other organisations around. Further, there is/are hardly any psychological investigation aimed at unearthing either organisational or

Requests for copies should be addressed: SK Singh, Assistant Professor HRD, New Dehli Institute of Management, 60 \& 61 Tughlakabad Insitutional Area, New Dehli, 110062, India personal factors contributing to the role effectiveness of newspaper reporters/ correspondents. Its because of this very simple reason that the present study aims at finding out factors, both organisational as well as personal, which help a newspaper reporter/ correspondent to become effective in his/her role. But good number of psychological studies conducted in India as well as abroad in organisations other than newspaper have come to the findings that there are certainly good number of both organisational as well as personal variables contributing to the role efficacy of individual/s in an organisation.

\section{Role efficacy: An overview}

Role efficacy is the effectiveness of a person in-a-role-in-anorganisation and this in turn depends on person's potential effectiveness, the potential effectiveness of the role being performed, and the internal environment of the organisation (Pareek, 1993). In a sense, role efficacy is different from personal efficacy which refers to person's potential effectiveness in personal and interpersonal situations (Pareek, 1993). Thus, while looking at what role efficacy refers to one may come to pinpoint broadly two correlates - personal as well as organisational. The following section would depict research findings dealing with personal and organizational correlates of role efficacy.

\section{Personal Correlates of Role Efficacy}

An effective person in a role in an organisation is one who is an optimiser in utilizing all available and potential resources material, human, and financial - both within and outside the organization for its sustained long-term functioning (Campbell et al., 1970). For Rao (1981), person in any kind of organisational role may be effective if he/she understands his/her job requirements well, is aware of and utilizing his/her own and his/her subordinates' strengths and weakness in performing a given task, overcoming weaknesses and acquiring new capabilities through continuous learning on the job. According to various models ( e.g. Cummings and Schwab, 1973; Porter and 
Lawler, 1968; and Vroom, 1964), performance in an organisational setting is a function of at least three variables, namely, motivational level, role perception, and persistence of behaviour. Finally, the relationship between biographical information and success has also been explored (Child and Klimoski, 1986; Jencks, 1979; and Kenagy and Yoakum, 1925); and factors of biographical information have been found to be related to career success (Child and Klimoski, 1986) and role effectiveness (Singh and Dhillon, 2003).

Organisational Correlates of Role Efficacy

Researches in the field have also found some of the organisational variables affecting positively and some affecting negatively to the role effectiveness of an individual in an organisational setting. The internal environment of organisation characterised by control and affiliation seems to lower role efficacy (Brahaman and Pareek, 1982; Sen, 1982; and Surti, 1983); whereas innovation fostering climate affects positively to employees' role efficacy (Deo, 1993). Gupta and Khandelwal (1985) in a study found supervisory behaviour as the most important dimension contributing to role efficacy of employees. It is also to be noted down that role efficacy has been found to have strong linkage with appropriate structure, position power, and task structure (Sayeed, 1992a). Further, within the context of the university departments, the result of study suggests that the grade awarded for research effectiveness predict climate more than the internal environment of the organisation predicting research effectiveness (West et al., 1999). On the other hand, role efficacy has been found to be adversely affected by organisational role stress. The research literature suggest that role efficacy to be negatively related to role anxiety (Deo, 1993); role conflict and role ambiguity to have deleterious effects on employees work performance (Fried et al., 1998; and Khan and Byosiere, 1992). Finally, a negative and significant correlations between role efficacy and eight role stresses (as well as total scores), all significant at 0.001 level, has also been reported (Sen, 1982).

On the whole, it may be asserted that neither organisational nor personal variables alone contribute to role efficacy but a combination of both. In the present investigation, the investigator has picked two personal variables (Biographical Information and Journalistic Writing Attitude) and two organisational variables (Organisational Climate and Organisational Role Stress) to study their relationships and also their relative impact on to the consequent variable of role efficacy.

\section{METHODS}

Variables:

The following variables were studied in the present investigation as:

\section{Independent Variables}

(a) Organisational Climate

(b) Organisational Role Stress

(c) Journalistic Writing Attitude

(d)Background Information

\section{Dependent Variable}

Role Efficacy

\section{Objectives of the Study:}

The objectives of the study were:

1) To investigate the relationship of the antecedent variables of background information, organisational climate, organisational role stress, and journalistic writing attitude with the outcome variable of role efficacy of two hierarchical levels of reporters.

2) To examine the predictors or relative contribution of the antecedent variables (i.e. background information, organisational climate. organisational role stress, and journalistic writing attitude) onto the role efficacy of two hierarchical levels of reporters.
Hypotheses:

The following hypotheses were formulated in the study, as

1) There will be significant relationships between antecedent variables (i.e. biographical information, organisational climate, organisational role stress, and journalistic writing attitude) and the consequent variable of role efficacy for both the lower level and the higher level reporters.

2) The independent variables of biographical information, organisational climate, organisational role stress, and journalistic writing attitude will significantly predict role efficacy/effectiveness of both lower level and higher level reporters.

\section{Sample:}

The sample of the study consisted of broadly two group of staff reporters/correspondents - the lower level reporters (the LLRs) and the higher level reporters (the HLRs) - of the newspapers. The reporters having the designation upto the chief reporter/metro editor in the hierarchical ladder formed one group and consequently named the LLRs; whereas those having designation of correspondent and above up to the bureau chief formed another group and named the HLRs. This grouping of reporters/correspondents was based on the logic that the LLRs had the prime duty of collecting and reporting the local news primarily, whereas the HLRs had the duty and responsibility of covering, collecting, and reporting news emanating specially from ministries, legislative assemblies, parliament, governmental bodies, big business houses, political organisations, and the likes. Moreover, 58 were the LLRs and 42 were the HLRs in this study and this sample was drawn at random from eight national dailies published from Delhi, India.

\section{Measures Used:}

The following psychological instruments were used in this study, as:

(i) Organisational Climate Inventory, Form "B" [Developed by Chattopadhyaya and Agarwal, (1988)]

(ii) Organisational Role Stress Questionnaire [Developed by Pareek, (1983)]

(iii) Journalistic Writing Attitude Scale [Developed by Singh, (2001)]

(iv) Role Efficacy Scale [Developed by Pareek, (1993)]

(v) Personal Data Sheet [Developed by the Investigators]

Description of the Psychological Scale Used: Organisational Climate Inventory (OCI):

The OCI. Form 'B' used in this study was developed by Chattopadhyaya \& Agarwal (1988). The scale has 70 items comprising of eleven dimensions and a total score. The eleven dimensions in this scale are Performance Standards (PS), Communication Flow (Cf), Reward System (Rsy), Responsibility (Res), Conflict Resolution (Cr), Organisational Structure (Ostru), Motivational Level (Ml), Decision-Making Process (Dmp), Support System (Ssu), Warmth (Warm), and Identity Problems (Ipro).

Organisational Role Stress Questionnaire (ORSQ):

The ORSQ used in this study was developed and standardised on the Indian population by Pareek (1983). It has fifty items divided into ten dimensions and a total score. The ten dimensions of the scale are Inter-Role Distance (IRD), Role Stagnation (RS), Role-Expectation Conflict (REC), Role Erosion (RE), Role Overload (RO), Role Isolation (RI), Personal Inadequacy (PI), Self-Role Distance (SRD), Role Ambiguity (RA), and Resource Inadequacy (Rin).

Role Efficacy Scale (RES):

The role efficacy scale was developed and standardised by Pareek (1993) and has twenty items comprising of ten dimensions and 
a total score. The ten dimensions of the RES are Self-Role Integration (Sri), Proactivity (Pro), Creativity (Cre), Confrontation (Conf), Centrality (Cen), Influence (Inf), Personal Growth (Pg), Inter-Role Linkage (Irl), Helping Relationship (Hrel), and Superordination (Super).

Journalistic Writing Attitude Scale (JWAS):

The JWAS was developed by the Singh (2001) to measure journalistic writing attitude of the newspaper reporters. This scale was standardised on 100 newspaper reporters working for major national dailies published from Delhi, India. After factor analysis and the Scree test, eight dimensions were identified. The eight dimensions are Writing Skills (Ws), Societal Sensitivity (Ssen), Content Consciousness (Ccon), Judiciously Balanced Reporting (Jbr), Jargon Writing (Jw), Facts Presentation (Fpre), Outgoingness (Ogo), and Personal Characteristics (Pc). The scale has altogether 25 items and each item is to be rated by the respondent on a 5-point response category. The scale also has provision for a total score.

Personal Data Sheet (PDS):

The personal data sheet was developed by the investigators to obtain information regarding the respondents Age, Sex, Education (Edu), Marital Status (MaS), Number of Dependents (Nod), Designation (Desi), Number of years in Present Position (Nypp), Total Work Experience (Twe), and Total No. of Promotions (Tnp).

Statistical Treatment of Data:

The data collected were subjected to the following statistical treatments, as:

(i) Correlational Analysis (Pearson's Product-Moment Correlation)

(ii) Multiple Regression Analysis - Stepwise

\section{RESULTS AND DISCUSSION}

The purpose of the study was to find out the nature as well as kind of relationship between independent variables of biographical information, organisational climate, organisational role stress, and journalistic writing attitude with the dependent variable of role efficacy/effectiveness of both the LLRs and the HLRs. The study also aimed at investigating the impact or contribution of the antecedent variables (i.e., biographical information, organisational climate, organisational role stress, and journalistic writing attitude) onto the role effectiveness of both the lower level as well as the higher level reporters.

The table 1 and the table 2 depict the obtained correlation coefficients between role efficacy and its dimensions with the biographical information, organisational climate, organisational role stress, journalistic writing attitude for the LLRs and the HLRs respectively. The results suggest that role efficacy/ effectiveness and its dimensions have significant positive relationships with perception of organisational climate but have significant negative relationships with felt/perceived role stress for both the lower level and the higher level reporters. This may be interpreted that as both the LLRs and the HLRs perceive the internal environment of their organisation favourly there is an increment in theirs being effective in the roles in the organisation. On the other hand, as both the LLRs and the HLRs perceive more of role stress emanating due to conflicting expectations from boss, colleagues and subordinates/juniors, too much of work to be done effectively in too little time, perception of their roles being isolated from other similar roles in the organisation, inadequate resources, and the likes there is a decrement in their role effectiveness.

TABLE 1

Correlation of Role Efficacy and its dimensions with Background Variables, Organizational Climate, Organizational Role Stress AND Journalistic Writing ATtitude for Lower LeVel Reporters (N=58)

\begin{tabular}{|c|c|c|c|c|c|c|c|c|c|c|c|}
\hline (BV) & SRI & Pro & $\mathrm{Cr}$ & Conf & Cen & Inf & Pg & Irl & Hrel & So & Total \\
\hline Age & $-.29^{*}$ & & & & & & & $.26^{*}$ & $-.28^{*}$ & & \\
\hline MaS & & & & & & & & $.37 * *$ & $-.26^{*}$ & & \\
\hline Nod & $-.26^{*}$ & & & & & & & & & & \\
\hline Nypp & & & & & & & & & & $.37^{* *}$ & \\
\hline Twe & $-.33^{* *}$ & & & & & & & $.36^{* *}$ & $-.26^{*}$ & & \\
\hline Tnp & & & & & & & & $.42^{* *}$ & & & \\
\hline \multicolumn{12}{|l|}{$(O C)$} \\
\hline $\mathrm{Cf}$ & & & & & & & & $.25^{*}$ & & & \\
\hline Ostru & & $.30^{*}$ & & & & & $.29^{*}$ & & & & $.38^{* *}$ \\
\hline Ml & & & & & & & & $.26^{*}$ & & & \\
\hline Dmp & & $.29^{*}$ & & & & & & & & & \\
\hline Ssu & & & & & & & & $.33^{* *}$ & & & \\
\hline Warm & & & & & & & & $.25^{*}$ & & & \\
\hline \multicolumn{12}{|l|}{ (ORS) } \\
\hline RS & $-.28^{*}$ & & & & & & & & & & \\
\hline REC & & & & $-.34^{* *}$ & & & $-.34^{* *}$ & & & & \\
\hline RO & & & & & & & $-.28^{*}$ & $-.32^{*}$ & & & $-.29^{*}$ \\
\hline RI & & $-.27 *$ & & & $-.27 *$ & & $-.25^{*}$ & $-.30^{*}$ & & & \\
\hline PI & & $-.31^{*}$ & & & & & $-.26^{*}$ & & & $.30^{*}$ & $-.33 * *$ \\
\hline SRD & & & & & $-.33^{* *}$ & & & & & & $-.28^{*}$ \\
\hline RA & & $-.26^{*}$ & & & & & & & & & \\
\hline Rin & & & & $-.27^{*}$ & $-.31^{*}$ & & & $-.26^{*}$ & & & \\
\hline Total & & & $-.30^{*}$ & & & $-.30^{*}$ & & & & $-.27 *$ & $-.26^{*}$ \\
\hline \multicolumn{12}{|l|}{$(J W A)$} \\
\hline Ssen & & & & $.26^{*}$ & & & & & & & \\
\hline Ccon & & & & & & & & & $.29^{*}$ & & \\
\hline Jbr & & & & & & & $.25^{*}$ & & & & $.25^{*}$ \\
\hline Fpre & & $.29 *$ & & $-.29^{*}$ & & & & & & $.25^{*}$ & \\
\hline Ogo & & & & & & & & & & & $.26^{*}$ \\
\hline Pc & & & & $-.28^{*}$ & & $-.36^{* *}$ & & & & & $-.34^{* *}$ \\
\hline
\end{tabular}

(Role Efficacy and its Dimensions)

** $\mathrm{p}<0.01$

${ }^{*} \mathrm{p}<0.05$ 
TABLE 2

Correlation of Role Efficacy and its dimensions with Background Variables, Organizational Climate, Organizational Role Stress and Journalistic Writing AtTitude for Higher LeVel Reporters (N=42)

\begin{tabular}{|c|c|c|c|c|c|c|c|c|c|c|c|}
\hline$(B V)$ & SRI & Pro & $\mathrm{Cr}$ & Conf & Cen & Inf & $\mathrm{Pg}$ & Irl & Hrel & Super & Total \\
\hline Age & $-.33^{*}$ & & & & & & & & & & \\
\hline Edu & & & & $-.35^{*}$ & $.37^{*}$ & & & & $-.30^{*}$ & & \\
\hline MaS & & & & & $.46^{* *}$ & $.35^{*}$ & & $.33 *$ & & $.30^{*}$ & $.30^{*}$ \\
\hline Nod & & & & & & & $-.29 *$ & & & & \\
\hline Nypp & & & & & & & & & $-.38 * *$ & & \\
\hline \multicolumn{12}{|l|}{$(O C)$} \\
\hline PS & $.51 * *$ & $.34 *$ & & & & $.34^{*}$ & $.38^{* *}$ & & & & $.57 * *$ \\
\hline Cf & & & & & & & $.32 *$ & & $.30^{*}$ & & \\
\hline Rsy & & & & & & $.29 *$ & & & $.29 *$ & & \\
\hline Res & & & & & & & & & $.42 * *$ & & \\
\hline $\mathrm{Cr}$ & $.37^{*}$ & & & & & & $.33 *$ & & & & $.37^{*}$ \\
\hline Ml & & & & & & $.37^{*}$ & & & & & \\
\hline Dmp & & & & & & $.34^{*}$ & & & & & \\
\hline Ipro & & & & & & & & $.34^{*}$ & & & $.32 *$ \\
\hline Total & & & & & & $.34^{*}$ & & & $.31 *$ & & $.31 *$ \\
\hline \multicolumn{12}{|l|}{ (ORS) } \\
\hline IRD & & $-.49^{* *}$ & & & & & & & & $-.34 *$ & \\
\hline RS & $-.34^{*}$ & $-.37^{*}$ & & & & & & & & & $-.38^{* *}$ \\
\hline REC & $-.37^{*}$ & & & & & $-.29 *$ & $-.45^{* *}$ & & & & $-.33^{*}$ \\
\hline $\mathrm{RE}$ & $-.45^{* *}$ & & & & & & & $-.42^{* *}$ & & & $-.48 * *$ \\
\hline RO & $.32 *$ & & & & $.33^{*}$ & & & & & & $.32^{*}$ \\
\hline RI & $-.38 * *$ & $-.34^{*}$ & & & & -.47 ** & & $-.54^{* *}$ & & $-.30^{*}$ & -.59 ** \\
\hline SRD & $-.32 *$ & & & & & & & & & & $-.31 *$ \\
\hline Rin & -.43 ** & & $-.31 *$ & & $-.38^{* *}$ & & & & & & $-.31^{*}$ \\
\hline Total & -.43 ** & & $-.31^{*}$ & & & & $-.30 *$ & $-.29 *$ & & & $-.47^{* *}$ \\
\hline \multicolumn{12}{|l|}{ (JWA) } \\
\hline Ws & & & & & & $.29 *$ & & & & & \\
\hline Ccon & & & & & $.30^{*}$ & & & & & & \\
\hline $\mathrm{Jw}$ & & & & & & & $-.39 * *$ & & & & \\
\hline Fpre & & $-.30 *$ & & & & $-.33^{*}$ & & & $-.36^{*}$ & & \\
\hline Total & & & & & & & $-.32 *$ & & & & \\
\hline
\end{tabular}

(Role Efficacy and its Dimensions)

${ }^{* *} \mathrm{p}<0.01$

${ }^{*} \mathrm{p}<0.05$

As for the relationships between role efficacy and its dimensions with biographical information and journalistic writing attitude, the table 1 and table 2 show that mixed relationships do exist. In other words, it can be said that some of the dimensions of role efficacy are positively related and some negatively related with background variables and attitudes toward journalistic writing for both the lower level and the higher level reporters. For the obtained significant correlation coefficients between role efficacy and its dimensions with journalistic writing attitude and its dimensions for both the LLRs and the HLRs, it may be said that becoming socially sensitive, content conscious, and presenting a balanced views while writing any happening of the society, there is an increment in their role effectiveness. Whereas, as the LLRs and the HLRs start approaching any kind of news with preconceived notions and thereafter writing/reporting those happenings in their newspaper using good amount of journalistic jargons and the likes, their role effectiveness decreases. On the other hand, the obtained results also indicate that as both the LLRs and the HLRs grow older in age, have more work experience and the likes, they start perceiving/feeling that theirs skills, knowledge, expertise, etc are not adequately utilised in the roles that they have been occupying and also that no help is forthcoming whenever the situation demands from the boss or the peers or the subordinates; and such a perception of the roles help decrease their role effectiveness.

On the whole, it may be asserted that not all but most of the obtained correlation coefficients have been found to be significant at either 0.05 or 0.01 level of significance. Thus, it may be said that the hypothesis stating significant relationships between the antecedent and the consequent variable have been found to be true and as a result of this that the stated hypothesis is accepted here.
Finally, table 3 and table 4 depict the results obtained for the contributions and the impact of the antecedent variables on to the role efficacy of the LLRs and the HLRs respectively. The table 3 shows that $39 \%$ of the variance in the total variance of the role effectiveness of the lower level reporters have been predicted. Further, it may also be looked into the table that out of $39 \%$ of the total variance in the role effectiveness $14 \%$ is contributed by organisational climate whereas the remaining $25 \%$ is contributed by journalistic writing attitude. Thus, it may be said that the remaining $61 \%$ of the variance in the role effectiveness for the LLRs is still unexplained; that means there may be some other variables that may be contributing to the role effectiveness along with the variables of organisational climate and journalistic writing attitude. On the other hand, the table 4 shows that $60 \%$ of the variance in the total variance of role efficacy of the HLRs have been predicted by some of the dimensions of organisational climate and organisation role stress. It also indicates that out of $60 \%$ of the variance in the total variance of role efficacy, $35 \%$ is contributed by the variable of organisational role stress and the remaining $25 \%$ by the organisational climate. Therefore, in the case of the HLRs, $40 \%$ of the total variance in theirs role effectiveness is still to be explained. Here too, it can be said that there may be some other variables along with the aforesaid variables of the organisational role stress and organisational climate that might be contributing to the role effectiveness of the higher level reporters.

On the whole, it may be said that the obtained results support the hypothesis that the antecedent variables under study do significantly predict to the role effectiveness of both the LLRs and the HLRs. 
TABLE 3

Multiple Regression Analysis STEPWise of Role EfFicacy (THE Dependent Variable) FOR LOWER LEVEL Reporters $(\mathbf{N}=\mathbf{5 8})$

\begin{tabular}{lcccccc}
\hline Independent Variable/s & \multicolumn{6}{c}{ Dependent Variable: Role Efficacy } \\
& $\mathbf{R}$ & $\mathbf{R}^{2}$ & $\mathrm{DR}$ & $\beta$ & $\mathrm{F}$ & $\boldsymbol{P}$ \\
\hline Organizational Structure & .38 & .14 & .00 & .38 & 9.22 & .0036 \\
Personal Characteristics & .51 & .26 & .12 & -.35 & 9.75 & .0002 \\
Content Consciousness & .56 & .31 & .05 & .23 & 8.27 & .0001 \\
Outgoingness & .62 & .39 & .08 & .28 & 8.41 & .0000 \\
\hline
\end{tabular}

TABLE 4

Multiple Regression Analysis -

STEPWISE OF Role EFficacy (THE DEPENDENT VARIABle) FOR Higher LeVEl Reporters $(\mathbf{N}=\mathbf{4 2})$

\begin{tabular}{lcccccc}
\hline Independent Variable/s & \multicolumn{7}{c}{ Dependent Variable: Role Efficacy } \\
& $\mathbf{R}$ & $\mathbf{R}^{2}$ & DR & $\beta$ & F & $\boldsymbol{P}$ \\
\hline Role Isolation & .59 & .35 & .00 & -.59 & 21.11 & .0000 \\
Performance Standards & .71 & .50 & .15 & .42 & 19.50 & .0000 \\
Warmth & .77 & .60 & .10 & -.35 & 18.92 & .0000 \\
\hline
\end{tabular}

\section{CONCLUSIONS}

On the basis of the analysis of the data, the following conclusion could be drawn:

1. For the LLRs and the HLRs, some of the dimensions of background variables are positively related and some negatively related to the role efficacy. On the other hand, for both the LLRs and the HLRs, the variables of organisational climate and organisational role stress are respectively positively and negatively related to the theirs role effectiveness. Finally, the dimensions of journalistic writing attitude viz. societal sensitivity, judiciously balanced reporting, content consciousness, and outgoingness are positively related to the role efficacy of the LLRs; similarly writing skills and content consciousness dimensions of the journalistic writing attitude have been found to be positively related to the role effectiveness of the HLRs. Apart from this, some of the dimensions of the journalistic writing attitude have been found to be negatively related to the role effectiveness of both the LLRs and the HLRs.

2. For the LLRs, the most potent predictors/determinants of role efficacy/effectiveness is journalistic writing attitude, followed by organisational climate. On the other hand, for the HLRs the most potent predictors of role efficacy/effectiveness are organisational role stress and organisational climate.

\section{Implications}

The present study has some implications for the newspaper organisation as:

1. The management of the newspaper organisation must work towards creating a congenial work climate with particular emphasis on performance standards, organisational structure, warmth, and the likes.

2. The management in the newspaper industry should work consciously towards minimizing role stress being felt by its staff reporters/correspondents particularly due to role isolation, role-expectation conflict, and the system of giving rewards.
Limitations and suggestions

Limitations are inherent in every research investigation and so the present study is not an exception. Here, along with limitations, suggestions for further research are presented as:

1. The researcher due to time constraints and finances could not locate any empirical study onto the role effectiveness of the newspaper reporters; and as a result, the findings of the present study could not be compared with the findings of other researches, if any, in the field.

2. The findings of the study indicate only about $40 \%$ to $60 \%$ of the variance in the total variance of the role efficacy/ effectiveness of the LLRs and the HLRs. It may mean that some other variables are also significant and the future research in this area should include some more variables so that more could be known about the factors contributing to the role effectiveness of the newspaper reporters.

\section{REFERENCES}

Brahman, D. N. \& Pareek, U. (1982). Motivational Climate in Bharat Engineering Ltd. In U. Pareek, T. V. Rao, and D. M. Pestonjee (Eds.), Behaviourial Processes in Organisations. New Delhi: Oxford and IBH.

Campbell, J.P., Dunnette, M. D., Lawler, E. E. III. \& Weick, K. E. Jr. (1970). Managerial Behaviour, Performance, and Effectiveness. New York: McGraw Hill.

Chattopadhyaya, S. \& Agarwal, K. G. (1998). Manual for Organisational Climate Inventory, Form 'B'. National Psychological Corporation, Kacheri Gate, Agra, India.

Childs, A. \& Klimoski, R. J. (1986). Successfully Predicting Career Success: An Application of the Biographical Inventory. Journal of Applied Psychology, 71.

Cummings, L. L. \& Schwab, D. (1973). Performance in Organisations. Glenview, IL: Scott, Foresman.

Deo, T. P. (1993). A Study of Some Psychological Correlates of Role Efficacy in Organisations from the Information Technology Industry. Unpublished Doctoral Dissertation in Psychology, University of Bombay, India.

Fried, Y., Ben-David, H. A., Tiegs, R. B., Avital, N. \& Yeverechyachu, U. (1998). The Interactive Effects of Role Conflicts and Role Ambiguity on Job Performance. Journal of Occupational and Organisational Psychology, 71.

Jencks, C. (1979). Who Gets Ahead? New York: Basic Books.

Kahn, R. L. \& Byosiere, P. (1992). Stress in Organisations. In M. D. Dunnette (Eds.), Handbook of Industrial and Organisational Psychology, 3, Palo Atto C A: Consulting Psychologists Press.

Kenagy, H. C. \& Yoakum, C. S. (1925). The Selection and Training of Salesman. New York: McGraw-Hill.

Pareek, U. (1983). Organisational Role Stress (Manual, Scale, and Answer Sheet). Navin Publications, Ahmedabad, India.

Pareek, U. (1993). Making Organisational Roles Effective. New Delhi: Tata McGraw Hill.

Sayeed, O. B. (1992). Role Making Behavioural, Organisational Priorities and Managerial Situational Control. Indian Journal of Industrial Relations, 27 (4).

Sen, P. C. (1981). A Study of Personal and Organisational Correlates of Role Stress and Coping Strategies in Some Public Sector Banks. Unpublished Ph. D. Thesis. Gujarat University, India.

Singh, S. K. (2001). Organisational and Personal Predictors of Effectiveness of Newspaper Reporters. Doctoral Dissertation in Psychology, University of Delhi, Delhi, India.

Singh, S. K. \& Dhillon, P. K. (2003). Role Effectiveness: A Comparative Study of Male and Female Newspaper Reporters. Indian Journal of Industrial Relations, 39 (1).

Surti, K. (1983). Role Stress and Coping Styles of Working Women. Doctoral Dissertation in Psychology, Gujarat University, India.

West, M. A., Smith, H., Feng, W. L. \& Lawthom, R. (1999). Research Excellence and Departmental Climate in British Universities. Journal of Occupational and Organisational Psychology, 71.

Vroom, V. (1964). Work and Motivation. New York: Wiley. 